\title{
Potential Role for Somatostatin Analogues in Breast Cancer: Rationale and Description of an Ongoing Trial
}

\author{
Michael Pollak, Karen Gallant, Roger Poisson, and Alan Harris
}

Somatostatin analogues such as octreotide have been shown in experimental systems to exhibit antineoplastic activity. Further laboratory and clinical research is needed to clarify the mechanism of action of somatostatin analogues as antineoplastics, and to determine if the encouraging preclinical results will lead to novel endocrine approaches to the treatment of breast cancer.

$\mathbf{T}$ HE ROLE OF HORMONES such as estrogen in stimulating the proliferation of endocrine-dependent human breast cancer is well established. ${ }^{1}$ Furthermore, endocrine treatments currently used to palliate metastatic breast cancer are among the most useful antineoplastic therapies available. Recent basic research concerning the dependence of neoplasms on peptide hormones and growth factors suggests that it may be possible to develop approaches that will extend the usefulness of this modality of cancer treatment. ${ }^{2}$

An important example of this is the current interest in the role of somatostatin in the regulation of cellular proliferation and the potential for therapeutic intervention using Sandostatin $^{\otimes}$, a long-acting synthetic analogue of this natural inhibitory peptide.

\section{RATIONALE}

Somatostatin analogues have been shown to inhibit the growth of a wide variety of tumors, both in culture and in various animal models. ${ }^{3-5}$ However, it is unclear at present by which mode of action somatostatin analogues exert their inhibitory effects.

First, it has been demonstrated that a majority of breast cancer cells are insulin-like growth factor I (IGF-I)-receptor positive and that the growth of these cells may be IGF-Idependent. ${ }^{6-10}$ This is supported by experiments demonstrating that blockade of the IGF-I receptor using a monoclonal antibody inhibits the growth of human breast cancer cell lines. "In fact, there is increasing evidence to suggest that IGF-I is one of the most potent breast cancer mitogens, perhaps more potent than estrogens. ${ }^{6}$ Data from a preliminary trial indicate that it is possible to lower circulating IGF-I levels by means of Sandostatin ${ }^{\star}$ administration. ${ }^{12}$ In a manner analogous to treatments that effectively palliate steroid-dependent neoplasms by lowering levels of estrogens and androgens, such an approach may be of therapeutic value for IGF-I-dependent tumors.

There is also evidence for direct antiproliferative effects of somatostatin analogues. In two series of human breast cancer primary trials, greater than $30 \%$ of the biopsy samples demonstrated high-affinity somatostatin-binding sites. ${ }^{13.14}$ Potential consequences of receptor binding include interference with transmission of intracellular signals that regulate growth, ie, through activation of a dephosphorylation process, ${ }^{15}$ inhibition of centrosomal separation, ${ }^{16}$ and through the inhibition of synthesis and/or secretion of other autocrine growth factors by tumor cells. ${ }^{17,18}$

Finally, the structurally related lactogenic hormones, growth hormone and prolactin, may influence the growth of breast cancer cells. ${ }^{19}$ Recent laboratory work has demonstrated that human prolactin receptors can bind both prolactin and growth hormone, and it has also confirmed that many breast cancer cells bear receptors for both prolactin and growth hormone. ${ }^{20,21}$ Initial clinical trials designed to test the value of pharmacologically decreasing prolactin levels in advanced disease were uniformly negative. ${ }^{22,23}$ However, a more recent study performed in early-stage disease patients has shown that bromocriptine significantly decreases the labeling index of breast tumors when administered perioperatively. ${ }^{24}$ Theoretically, the simultaneous use of an agent to decrease growth hormone levels (such as Sandostatin ${ }^{\otimes}$ ) and a dopamine agonist to decrease prolactin levels could result in a "selective medical hypophysectomy" that could interfere with lactogenic hormone stimulation of breast cancer cells.

\section{PATIENTS AND METHODS}

Based on these hypotheses, a study was designed to investigate, in open conditions, the antineoplastic activity of the somatostatin analogue, Sandostatin ${ }^{\circ}$, administered either as a single agent or coadministered with the dopamine agonist, CV 205-502 (Sandoz Canada Dorval, Quebec, Canada), in metastatic breast cancer. CV 205-502 is a new, long-acting, nonergot, dopamine $\mathrm{D}_{2}$-receptor agonist that has been shown to be effective in reducing serum prolactin levels in hyperprolactinemic patients when administered once a day. ${ }^{25}$

Estrogen receptor-positive patients of any menopausal status are eligible for study participation should they present with bidimensionally measurable metastatic breast cancer that has become refractory to antiestrogen treatment. The antiestrogen may have been administered in the adjuvant and/or metastatic disease setting. Patients of unknown estrogen-receptor status are also eligible if they are postmenopausal and have experienced a 2 -year, disease-free interval. $\mathrm{Pa}$ tients are not eligible if they have received any other antineoplastic therapy (chemotherapy, hormones, or nonpalliative radiation) for their metastatic disease other than an antiestrogen, or if they have rapidly progressing, life-threatening disease. Prior adjuvant chemotherapy is acceptable. Patients are randomized at entry to receive either $400 \mu \mathrm{g}$ Sandostatin ${ }^{\circledast}$ every 8 hours by subcutaneous injection or $400 \mu \mathrm{g}$ Sandostatin ${ }^{2}$ every 8 hours in combination with $0.075 \mathrm{mg}$ CV 205-502 orally once a day. Twenty patients per treatment group are planned. 
The end points of the study are as follows: (1) tumor response rates, and (2) endocrine and growth factor evaluations including serum prolactin, IGF-I, epidermal growth factor, estradiol, and urinary growth hormone.

\section{SUMMARY}

Despite recent advances, the treatment of breast cancer is still far from optimal. This is particularly true for those patients with advanced disease. Furthermore, with the high incidence of breast cancer, ${ }^{26}$ it is obvious that there is a need for improved therapies in the oncologist's armamentarium.

The somatostatin analogue, Sandostatin ${ }^{3}$, possesses unique and pleiotrophic actions that make it worthy of investigation in the clinical setting. The clinical trial described here has been designed to provide relevant data about both tumor responsiveness and the influence of Sandostatin ${ }^{\star}$ alone or in combination with CV 205-502 on endocrine and growth factor endpoints. This open-labeled, phase II study may generate data that will justify further evaluation of Sandostatin ${ }^{\star}$ in the adjuvant and/or palliative treatment of breast cancer, either as a single agent or in combination with dopamine agonists or, as recently proposed, with antiestrogens. ${ }^{27}$

\section{ACKNOWLEDGMENT}

We would like to thank our colleagues, including Dr Michael Thirlwell (Montreal General Hospital), Dr Shailendra Verma (Ottawa General Hospital), and the staff of the McGill University Department of Oncology for their participation in the study.

\section{REFERENCES}

1. Manni A: Endocrine therapy of breast and prostate cancer. Endocrinol Metab Clin North Am 18:569-592, 1989

2. Goustin AS, Leof EB, Shipley GD, et al: Growth factors and cancer. Cancer Res 46:1015-1029, 1986

3. Schally AU: Oncological applications of somatostatin analogues. Cancer Res 48:6977-6985, 1988

4. Lamberts SWJ, Koper JW, Reubi JC: Potential role of somatostatin analogues in the treatment of cancer. Eur J Clin Invest 17:281-287, 1987

5. Parmar H, Bogden A, Mollard M, et al: Somatostatin and somatostatin analogues in oncology. Cancer Treat Rev 16:95-115, 1989

6. Pollak MN. Polychronakos C, Yousef S, et al: Characterization of insulin-like growth factor-I receptors of human breast cancer cells. Biochem Biophys Res Commun 154:326-331, 1988

7. Furlanetto $\mathrm{R}$, Decarlo J: Somatomedin-C receptors and growth effects in human breast cells maintained in long term tissue culture. Cancer Res 44:2122-2128, 1984

8. Mayal Y, Shiv R, Bhavmick B, et al: Receptor binding and growth-promoting activity of insulin-like growth factors in human breast cancer cells in culture. Cancer Res 44:5486-5490, 1984

9. Pollak MN, Perdue J, Margolese R, et al: Presence of somatomedin receptors on primary human breast and colon carcinomas. Cancer Lett 38:223-230, 1987

10. Peyrat JP, Bonneterre J, Beuscart R, et al: Insulin-like growth factor I receptors in human breast cancer and their relation to estradiol and progesterone receptors. Cancer Res 48:6429-6433, 1988

11. Artega CL, Osbourne CK: Growth inhibition of human breast cancer cells in vitro with an antibody against the type I somatomedin receptor. Cancer Res 49:6237-6241, 1989

12. Pollak MN, Polychronakos C: Somatostatin analogue SMS 201-995 lowers IGF-I levels in patients with potentially IGF-I dependent cancers. Anticancer Res 9:889-892, 1989

13. Matyas F, Wittliff JL, Schally AV: Characteristics and distribution of receptors for [D-TRP-6]-luteinizing hormone-releasing hormone, somatostatin, epidermal growth factor, and sex steroids in 500 biopsy samples of human breast cancer. J Clin Lab Anal 3:137. 147,1989
14. Reubi JC, Waser B, Foekens JA, et al: Somatostatin receptor incidence and distribution in breast cancer using autoradiography: Relationship to EGF receptors. Int J Cancer 46:4 16-420, 1990

15. Liebow C, Lee MT, Schally A: Antitumor effects of somatostatin mediated by the stimulation of tyrosine phosphatasc. Metabolism 39:163-166, 1990

16. Mascardo RN, Sherline P: Somatostatin inhibits rapid centrosomal separation and cell proliferation induced by epidermal growth factor. Endocrinology 111:1394-1396, 1982

17. Venin PH, Peyrat JP, Bonneterre J, et al: Effect of the longacting somatostatin analogue SMS 201-995 (Sandostatin ${ }^{\circledR}$ ) in advanced breast cancer. Anticancer Res 9:153-156, 1989

18. Chirlanda G, Uccioli L, Perri F, et al: Epidermal growth factor, somatostatin and psoriasis. Lancet 1:65-73, 1983

19. Biswas R, Voderhaar BK: Role of serum in the prolactin responsiveness of MCF-7 human breast cancer cells in long-term tissue culture. Cancer Res 47:3509-3514, 1987

20. Boutin JM, Jolicoeur C, Okamura $\mathrm{H}$ : Cloning and expression of the rat prolactin receptor, a member of the growth hormone/prolactin receptor gene family. Cell 53:60-70, 1988

21. Peyrat JP, Djiane J, Kelly PA, et al: Characterization of prolactin receptors in human breast cancer. Breast Cancer Res Treat 4: 275-281, 1984

22. European Breast Cancer Group: Clinical trial of CB154 in advanced breast cancer. Eur J Cancer 8:155-162, 1972

23. Barrett A, Morgan L, Raggatt PR, et al: Bromocriptine in the treatment of advanced breast cancer. Clin Oncol 2:373-377, 1976

24. Fentiman I, Chaudary MA, Wang DY, et al: Perioperative bromocriptine as adjuvant treatment for operable breast cancer. Lancet: 609-610, 1988

25. Rasmussen C, Torbjorn B, Wide L, et al: Long-term treatment with a new non-ergot long-acting dopamine agonist, CV 205-502, in women with hyperprolactinemia. Clin Endocrinol 29:271-279, 1988

26. SEER data base, Bethesda, MD, National Cancer Institute, 1973-1987

27. Pollak M, Constantino J, Polychronakos C, et al: Effect of tamoxifen on serum IGF-I levels in stage 1 breast cancer. JNCI 82: $1693-1697,1990$ 